\title{
Two Separate Receptors for Prolactin in the Rabbit Mammary Gland
}

\author{
SENKITI SAKAI AND Fumio IKE* \\ Department of Animal Breeding, Faculty of Agriculture, \\ University of Tokyo, Bunkyo-ku, Tokyo 113, Japan \\ and \\ * Animal Physiology Laboratory, Institute of Physical and \\ Chemical Research, Wako-shi, Saitama 351-01, Japan
}

\begin{abstract}
Rabbit mammary gland PRL receptors in the microsome fraction were solubilized with the zwitterionic detergent Chaps, and were separated into two fractions (Fr. A and B) by ion-exchange chromatography. The number of receptors in Fr. B was about 2.2 times greater than in Fr. A. In sucrose gradient centrifugation analysis, PRL receptors in Fr. A and Fr. B sedimented at different positions. After binding ${ }^{125}$ I-PRL, the apparent molecular weight (mol wt) of the PRL receptor in Fr. A changed from 42,400 to 65,500 and that in Fr. B changed from 89,400 to 108,000 , suggesting that each binding subunit interacts with one PRL molecule. Cross-linking ${ }^{125}$ I-PRL to receptors revealed little change following SDS-PAGE, in the autoradiogram patterns of the microsome PRL receptors, either in the presence or absence of dithiothreitol. Both the microsome and the Chaps extract contained two major binding subunits (mol wt, 83,200 and 36,800) and one minor subunit (mol wt, 20,800). The mol wt of the dominant PRL receptors in Fr. A and Fr. B were 36,800 and 83,200 , respectively. The latter form did not dissociate into a $36,800 \mathrm{~mol}$ wt form, suggesting that the rabbit mammary gland contains two independent binding subunits with mol wt of 36,800 and 83,200 . Data showed that PRL receptors in the rabbit mammary gland are mostly the high $\mathrm{Kd}$ type receptor with a mol wt of 83,200 .
\end{abstract}

Received February 24, 1987

The abbreviations used were: SDS-PAGE, sodium dodecyl sulfate-polyacrylamide gel electrophoresis ; Fr., fraction; $\mathrm{K}_{\mathrm{d}}$, dissociation constant ; $\mathrm{S}$, sedimentation coefficient; DEAE, diethylaminoethyl ; Chaps, 3-[(3-cholamidopropyl)-dimethylammonio]-1-propane sulfonate; PMSF, phenylmethylsulfonyl fluoride; BSA, bovine serum albumin; DSS, disuccinimidyl suberate; PEG, polyethylene glycol 6000 ; DTT, dithiothreitol

To whom correspondence should be addressed: Dr. Senkiti SAKAI

Department of Animal Breeding, Faculty of Agriculture, University of Tokyo, Bunkyo-ku, Toky 113, Japan (Tel : 03-812-2111 Ext. 5382)
The membrane PRL receptors have been solubilized using the non- or (zwitterionic detergent (Triton X-100 or Chaps), with retention of binding activity (Shiu and Friesen, 1974 ; Liscia et al., 1982). Some of their physico-chemical properties in various tissues and species have been determined (Haeuptle et al., 1983; Katoh et al., 1984; Necessary et al., 1984; Sakai et al., 1985).

We have shown that Chaps-solubilized PRL receptors can be separated by ionexchange chromatography into two species, both of which had specificity and high affinity for PRL binding (Sakai et al., 1986). 
In this study, we examind the number of PRL receptors in different fractions by Scatchard analysis. After sucrose gradient centrifugation, the recovery of the PRL receptors was $100 \%$. Therefore, we further examined the sedimentation characteristics of PRL receptors fractionated by ion-exchange chromatography and their interaction with PRL under non-denaturing conditions. The molecular weight (mol wt) of the PRL receptors after affinity-labeling was examined by sodium dodecyl sulfate-polyacrylamide gel electrophoresis (SDS-PAGE) and autoradiography. The present experiments were undertaken as an initial step toward a future study of PRL receptor structure in the mammary gland.

\section{Materials and Methods}

\section{Hormone and chemicals}

PRL (NIH-P-S15, 30.5 IU/mg) was a gift from NIADDK, Bethesda, MD. SDS-PAGE mol wt standards and DEAE Bio-Gel A was purchased from Bio-Rad, Richmond, CA. Chaps was obtained from Sigma, St. Louis, MO. Disuccinimidyl suberate (DSS) was obtained from Pierce Chemical Co., Rockford, IL. The mol wt standards used for calibration of the sucrose gradient were obtained from Pharmacia Fine Chemicals, Uppsala, Sweden. All other chemicals were of the reagent grade.

\section{Solubilization and ion-exchange chromatography}

New Zealand White rabbits (6-12 days of lactation) were used. The mammary gland microsomes $(100,000 \times \mathrm{g}, 60 \mathrm{~min}$, pellet $)$ were suspended in $25 \mathrm{mM}$ Tris- $\mathrm{HCl}(\mathrm{pH} \quad 7.4) / 10 \mathrm{mM}$ $\mathrm{MgCl}_{2} / 1 \mathrm{mM}$ phenylmethylsulfonyl fluoride (TMP buffer) and treated with $7.5 \mathrm{mM}$ Chaps for 30 min at room temperature. The suspensions were centrifuged at $186,000 \times \mathrm{g}$ for $70 \mathrm{~min}$ at $4^{\circ} \mathrm{C}$. After centrifugation, the supernatant was collected and stored at $-80^{\circ} \mathrm{C}$ This fraction is referred to as the "Chaps extract". PRL receptors in the Chaps extract were analyzed by ion-exchange chromatography using DEAE Bio-Gel A. Approximately $30 \mathrm{mg}$ of protein was passed (at $4^{\circ} \mathrm{C}$ ) over a column $(1.3 \times 8 \mathrm{~cm})$ which had been equilibrated with $20 \mathrm{mM}$ Tris- $\mathrm{HCl}(\mathrm{pH} 7.4) / 7.5$ mM Chaps (TC buffer). The PRL receptors were eluted with a two-component gradient prepared from $100 \mathrm{ml} \mathrm{TC}$ buffer and $100 \mathrm{ml}$ TC buffer containing $200 \mathrm{mM} \mathrm{NaCl}$. This procedure was described previously (Sakai et al., 1986).

\section{$P R L$ binding to receptors}

PRL was iodinated by lactoperoxidase and hydrogen peroxide (Sakai et al., 1986). The radioactivity of ${ }^{125} \mathrm{I}-\mathrm{PRL}$ was $70-85 \mu \mathrm{Ci} / \mu \mathrm{g}$. For the binding assay (Sakai et al., 1985), receptors were incubated with $30,000 \mathrm{cpm}$ of ${ }^{125}$ I-PRL in the presence or absence of unlabeled RRL $(1 \mu \mathrm{g})$ for $16 \mathrm{~h}$ at room temperature. The total reaction volume and the final Chaps concentration were adjusted to $0.5 \mathrm{ml}$ with TMP buffer containing $0.1 \% \mathrm{BSA}$ and to $5 \mathrm{mM}$, respectively. After incubation, the reaction mixtures were combined with $0.5 \mathrm{ml}$ cold $0.1 \%$ gamma globulin in $0.1 \mathrm{M}$ phosphate buffer ( $\mathrm{pH} 7.4$ ) and $1 \mathrm{ml} 32 \%$ solution of polyethylene glycol 6000 (PEG), vortexed and centrifuged at $2,000 \times \mathrm{g}$ for $15 \mathrm{~min}$. At this concentration of PEG, unbound ${ }^{125} \mathrm{I}-\mathrm{PRL}$ in the reaction mixture remained soluble and was removed by decantation. Radioactivity in the precipitants was measured in a gamma counter with a counting efficiency of $60 \%$. Specific binding of ${ }^{125}$ I-PRL was calculated as the difference between the radioactivity bound in the presence and absence of unlabeled PRL. The amounts of non-specific bining of ${ }^{125}$ I-PRL were 3.0 to $5.0 \%$ of total radioactivity added. For Scatchard analysis (1949), the PRL receptors were incubated with ${ }^{125} \mathrm{I}-\mathrm{PRL}$ in the presence of $0.2,0.4,0.6,0.8,1.2,1.6,2.4$ and $3.2 \mathrm{ng}$ of unlabeled PRL. Each determination was performed in triplicate.

\section{Sucrose gradient centrifugation}

Analytical gradient centrifugation of the PRL receptors through $5 \mathrm{ml}$ of $5-22.5 \%$ sucrose gradients was used to estimate the sedimentation coefficient (S), as described previously (Sakai et al., 1986). Sucrose was dissolved in $25 \mathrm{mM}$ HEPES-NaOH (pH 7.4)/150 mM NaCl/7.5 mM Chaps. The gradients, prepared by the method of Luthe (1983), were stored at $-80^{\circ} \mathrm{C}$ and thawed $20 \mathrm{~h}$ prior to use at $4^{\circ} \mathrm{C}$. Gradients were calibrated using gamma globulin, BSA, ovalbumin, chymotrypsinogen A and ribonuclease A. All samples were filtered through $0.45 \mu \mathrm{m}$ Ekicrodisc 13 (Gelman Sciences Japan, Tokyo) 
to remove insoluble materials and $200 \mu \mathrm{l}$ of the sample was layered onto the gradients. The gradients were centrifuged at $204,040 \times \mathrm{g}$ (average) for $17 \mathrm{~h}$ at $5^{\circ} \mathrm{C}$ using a RPS-50 rotor in an 55P-72 ultracentrifuge (Hitachi Koki Co., Tokyo). Following centrifugation, a $150 \mu \mathrm{l}$ fraction was collected from the bottom of the tube. For the determination of PRL receptors, $70 \mu l$ of each fraction was used for estimation of total and non-specific binding of PRL, as described above. For analysis of the ${ }^{125}$ I-PRLreceptor complexes formed before ultracentrifugation, the PEG precipitation described above was carried out on a $100 \mu \mathrm{l}$ aliquot. The sucrose concentration at each separated zone was measured with a refractometer. The $\mathrm{S}$ value was calculated according to the method of McEwen (1967). The mol wt of the PRL receptor was estimated using the calculated $\mathrm{S}$ and the known mol wt of marker standards (Martin and Ames, 1961).

\section{Affinity-labeling of PRL receptors}

PRL receptors were incubated with 150,000 cpm $(0.1 \mathrm{pmol})$ of ${ }^{125} \mathrm{I}$-PRL in the presence or absence of a 1,000-fold excess of unlabeled PRL in the total reaction volume of $0.3 \mathrm{ml}$ for $16 \mathrm{~h}$ at room temperature. At the end of the incubation, $0.2 \mathrm{ml}$ of gamma globulin $(50 \mu \mathrm{g})$ and $0.5 \mathrm{ml}$ $40 \%$ PEG solution were added and the tubes were centrifuged at $12,000 \times \mathrm{g}$ for $15 \mathrm{~min}$. Under the conditions used in this series of experiments, the same amounts of total or nonspecific binding which were obtained by the standard PEG precipitation assay described above were recovered. The tubes were then washed once with a $20 \%$ solution of PEG. The precipitates were dissolved in $0.1 \mathrm{ml}$ of $10 \mathrm{mM}$ phosphate buffer (pH 7.4) containing $7.5 \mathrm{mM}$ Chaps. The crosslinking reagent DSS was dissolved in dimethylsulfonate oxide. The ${ }^{125}$ I-PRL-receptor complexes were then affinity-labeled using DSS at a final concentration of $0.75 \mathrm{mM}$ for $15 \mathrm{~min}$ on ice. The samples were denatured in the presence of $2 \%$ SDS and $100 \mathrm{mM}$ dithiothreitol (DTT) for $5 \mathrm{~min}$ in boiling water. Electrophoresis was performed on $7.5-20 \%$ linear gradient polyacrylamide slab gels ( $2 \mathrm{~mm}$ thickness) according to the method of Laemmli (1970). After SDS-PAGE, gels were stained with Coomassie Brilliant Blue, destained in acetic acid/methanol/water (10/25/65), dried at $75^{\circ} \mathrm{C}$ under vacuum, and exposed to Eastman Kodak X-Omat AR-5 films together with Dupon
Cronex Lightning Plus intensifying screens at $-80^{\circ} \mathrm{C}$.

\section{Results}

Solubilization and separation of PRL receptors About $35 \%$ of the microsome PRL receptors became soluble following treatment with $7.5 \mathrm{mM}$ Chaps. As shown in Fig. 1, PRL receptors in the Chaps extract were separated into two different fractions (Fr. A and B) by ion-exchange chromatography. PRL receptors in Fr. A and Fr. B were eluted with concentrations of 50-55 $\mathrm{mM}$ and $120-130 \mathrm{mM} \mathrm{NaCl}$, respectively. The percent distribution of the PRL-binding activity in the unbound-, $25-90 \mathrm{mM} \mathrm{NaCl}$ (A), and 100-180 $\mathrm{mM} \mathrm{NaCl}$ (B) fractions was $11.4 \%, 37.4 \%$ and $51.3 \%$, respectively (Table 1). PRL receptors in the Chaps extract, Fr. A and Fr. B were analyzed by Scatchard analysis. The dissociation constants $\left(\mathrm{K}_{\mathrm{d}}\right)$ for PRL binding to the

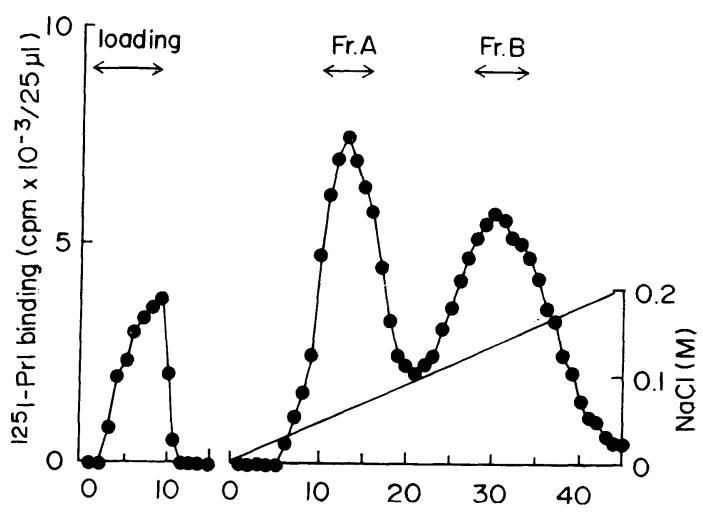

Fig. 1. Ion-exchange chromatography of PRL receptors in the Chaps extract. Fifteen tubes $(4.5 \mathrm{ml} /$ tube) of the unbound fraction and 45 tubes of the bound fraction were collected. Twenty-five $\mu$ l samples were used for PRL binding assay as described in the text. Horizontal bars with arrow heads indicate pools for Fr. A and B. The straight diagonal line with no points is the $[\mathrm{NaCl}]$ gradient. 
Table 1. Amounts of PRL binding by unbound and bound fractions separated by ion-exchange chromatography

The molar ratio of PRL receptors in pooled fractions of $25-90 \mathrm{mM}$ (A) and $100-180 \mathrm{mM} \mathrm{NaCl}$ (B) was calculated as follows. The amount of specific PRL binding was adjusted to $3,900-4,000 \mathrm{cpm}$ and Scatchard analysis was carried out according to the procedure described in the text.

\begin{tabular}{|c|c|c|c|c|}
\hline \multirow[t]{2}{*}{ Samples } & \multirow[t]{2}{*}{ Unbound } & \multicolumn{2}{|c|}{$\begin{array}{l}\text { Bound and eluted by } \\
\qquad \mathrm{NaCl}\end{array}$} & \multirow{2}{*}{$\begin{array}{c}\text { Ratio of } \\
\text { (A)/(B) } \\
(\mathrm{mol} / \mathrm{mol})\end{array}$} \\
\hline & & $\begin{array}{l}25-90 \mathrm{mM} \\
\text { (A) }\end{array}$ & $\begin{array}{l}100-180 \mathrm{mM} \\
\text { (B) }\end{array}$ & \\
\hline (1) & 203* & 857 & 997 & 0.51 \\
\hline (2) & 252 & 771 & 1,239 & 0.37 \\
\hline (3) & 249 & 703 & 906 & 0.49 \\
\hline (4) & 322 & 1,036 & 1,537 & 0.47 \\
\hline Means & 257 & 842 & 1,170 & 0.46 \\
\hline
\end{tabular}

receptors in the Chaps extract, Fr. A and Fr. B were $4.2 \pm 0.3\left(\times 10^{-11} \mathrm{M}\right.$, mean $\pm S D$, $\mathrm{n}=4), 3.0 \pm 0.4$, and $6.5 \pm 0.8$, respectively. The $K_{d}$ for PRL receptors in Fr. A was significantly different from that in Fr. B $(P<$ $0.05, t$-test). The number of PRL receptors in Fr. B was about 2.2 times larger in molar basis than in Fr. A (Table 1). The peak fractions of Fr. A or Fr. B, indicated in Fig. 1, were pooled individually and used for sucrose gradient centrifugation and affinity-labeling in the present experiments.

Characterization of $P R L$ receptors by sucrose gradient centrifugation and SDS-PAGE

PRL receptors in Fr. A and B were loaded on a $5-22.5 \%$ sucrose gradient and centrifuged at 204,040 X g for $17 \mathrm{~h}$ (Fig. 2). The recovery of PRL receptors after centrifugation was $100 \%$. PRL receptors in Fr. A behaved as single species and were sedimented at Fr. 13 with a sucrose concentration of $10.4 \%$. After binding to ${ }^{125} \mathrm{I}$ PRL, the peak position shifted to Fr. 18 containing $12.5 \%$ sucrose. The $\mathrm{S}$ values of the PRL receptor and PRL-receptor complex in Fr. A were calculated to be $3.56 \pm 0.08$ $(\mathrm{n}=5)$ and $4.67 \pm 0.10$, respectively. PRL receptors in Fr. B were sedimented at Fr. 20 containing $13.6 \%$ sucrose. After binding to ${ }^{125} \mathrm{I}-\mathrm{PRL}$, the peak position shifted to Fr. 22-23 (sucrose concentration of 14.7\%). The $S$ values of the PRL receptor and the PRL-receptor complex in Fr. B were 5.40士 0.30 and $5.86 \pm 0.12$, respectively. A high mol wt form of the PRL receptor was also found at the bottom of the tube. An apparent mol wt was estimated from a calibration curve constructed using marker proteins (Fig. 3). The $\mathrm{mol} \mathrm{wt}$ of free receptors in Fr. A and Fr. B were 42,400 and 89,400 , respectively. After binding to ${ }^{125} \mathrm{I}-\mathrm{PRL}$, their $\mathrm{mol} \mathrm{wt}$ increased to 65,500 and 108,000 .

After cross-linking with DSS, the ${ }^{125}$ IPRL-receptor complexes were analyzed by SDS-PAGE with a 7.5-20\% linear gradient acrylamide concentration. Regardless of the presence or absence of DTT, the positions of the mol wt standards were unchanged. But the migrated position of ${ }^{125}$ I-PRL differed depending on the presence or absence of DTT in denaturing buffer. The mol wt of ${ }^{125} \mathrm{I}-\mathrm{PRL}$ was estimated to be $23,000 \pm$ $800(n=5)$ in the absence or $26,800 \pm 1,100$ 


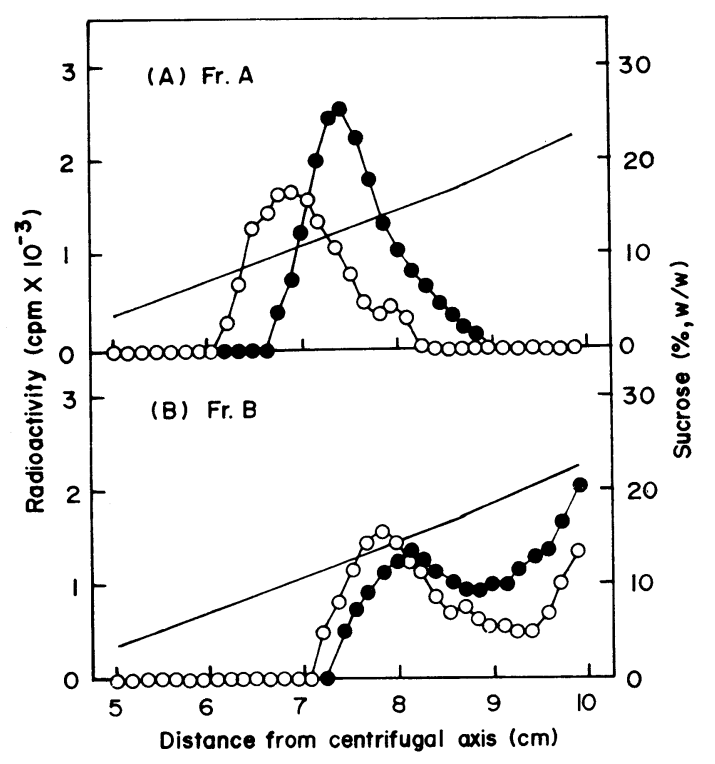

Fig. 2. Sucrose-gradient centrifugation of PRL receptors in Fr. A and Fr. B. The concentrations of protein in Fr. A and B were $370 \mu \mathrm{g} / \mathrm{ml}$ and $435 \mu \mathrm{g} / \mathrm{ml}$, respectively. Total and non-specific binding in Fr. A were $42,600 \mathrm{cpm} /$ centrifuge tube and $14,300 \mathrm{cpm}$, and those in Fr. B were $40,200 \mathrm{cpm}$ and $9,200 \mathrm{cpm}$, respectively. A $200 \mu \mathrm{l}$-portion of Fr. A or B was analyzed according to the procedure described in the text. Linear sucrose gradients were obtained from fractions of 1 to 25 . This range was used to calculate the $S$ value using the table for the particle density of 1.3 and $Z_{0}=-15$ (the closest value to -15.1) (McEwen, 1967). ${ }^{125}$ I-PRL reacted with PRL receptors before $(\boldsymbol{O})$ and after ultracentrifugation $(\bigcirc)$. The straight diagonal line shows the [sucrose] concentration.

in the presence of DTT. The microsome PRL receptors were denatured with SDS in the presence or absence of DTT. Both autoradiogram patterns of the PRL-receptor complexes were almost identical (Fig. 4). The solubilized and the ion-exchangefractionated samples were completely denatured with SDS and DTT. The value of 26,800 (the mol wt of ${ }^{125}$ I-PRL) was subtracted from the mol wt of each PRLreceptor complex. Autoradiography in Fig.

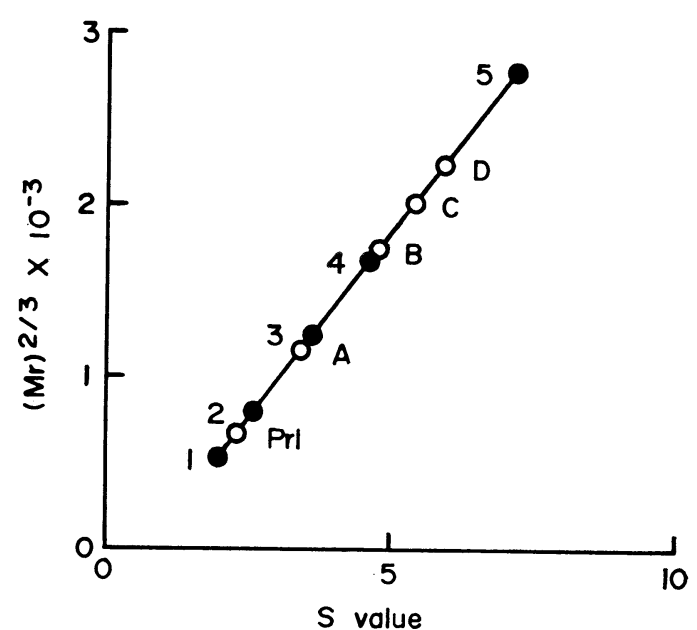

Fig. 3. A standard curve for estimation of the mol wt of PRL receptors constructed using calculated $\mathbf{S}$ values and known mol wt of standard proteins. Marker proteins with calculated $S$ values: 1 , ribonuclease A (2.00); 2 , chymotrypsinogen A $(2.55) ; 3$, ovalbumin (3.63); 4, BSA (4.72); 5, gamma globulin (7.10). A, free receptor in Fr. A; B, PRLreceptor complex in Fr. A; C, free receptor in Fr. B; D, PRL-Receptor complex in Fr. B.

5 shows that the Chaps extract contained three PRL-binding subunits with mol wt of $83,200 \pm 6,800,36,800 \pm 1,100$ and $20,800 \pm$ 1,600. Species and their mol wt were similar to those present in the microsomes. When PRL receptors were incubated with ${ }^{125} \mathrm{I}-\mathrm{PRL}$ in the presence of a 1,000-fold excess of unlabeled PRL, the band with a mol wt of 63,600 (receptor alone, 36,800) completely disappeared from the autoradiogram. Two other bands were faint but could be detected. The PRL receptors in Fr. A had mol wt of 83,200 and 36,800 , and the dominant species was the $36,800 \mathrm{~mol}$ wt receptor. Fr. B contained PRL receptors with mol wt of 83,200 and 20,800 , but did not contain the 36,800 species. 


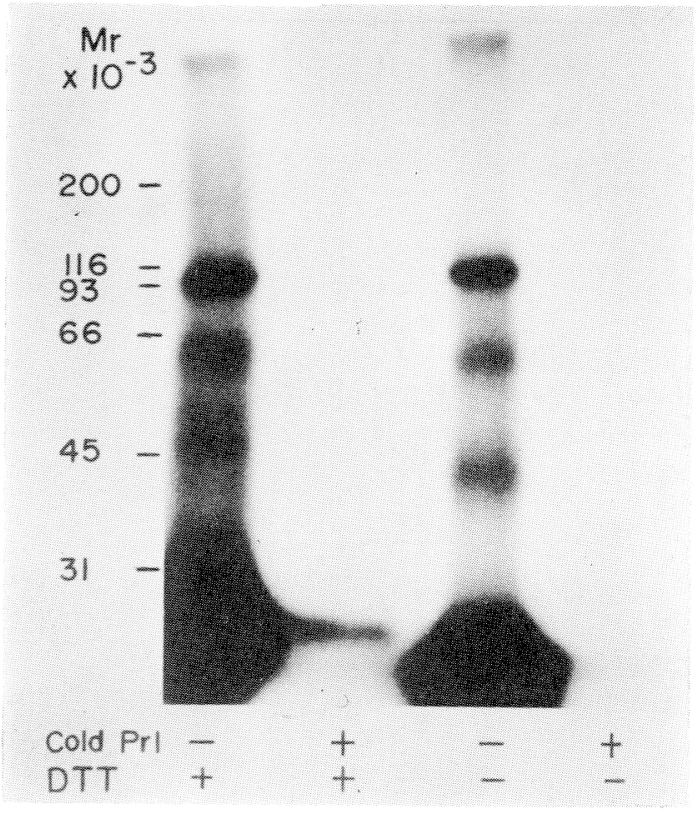

Fig. 4. Cross-linking of ${ }^{125}$ I-PRL-receptors complexes in microsomes. The microsomes were incubated with $150,000 \mathrm{cpm}$ of ${ }^{125} \mathrm{I}-\mathrm{PRL}$ in the presence or absence of a 1,000-fold excess of unlabeled PRL for $16 \mathrm{~h}$. After washing with phosphate buffer, microsomes were incubated with $0.75 \mathrm{mM}$ DSS for $15 \mathrm{~min}$ and then denatured with $2 \%$ SDS in the presence or absence of $100 \mathrm{mM}$ DTT. Forty $\mu \mathrm{g}$ protein was placed on polyacrylamide slab gels. Total and non-specific binding were $21,000 \mathrm{cpm}$ and $1,500 \mathrm{cpm}$ per lane. The positions of the mol wt standards are indicated on the left of the autoradiogram.

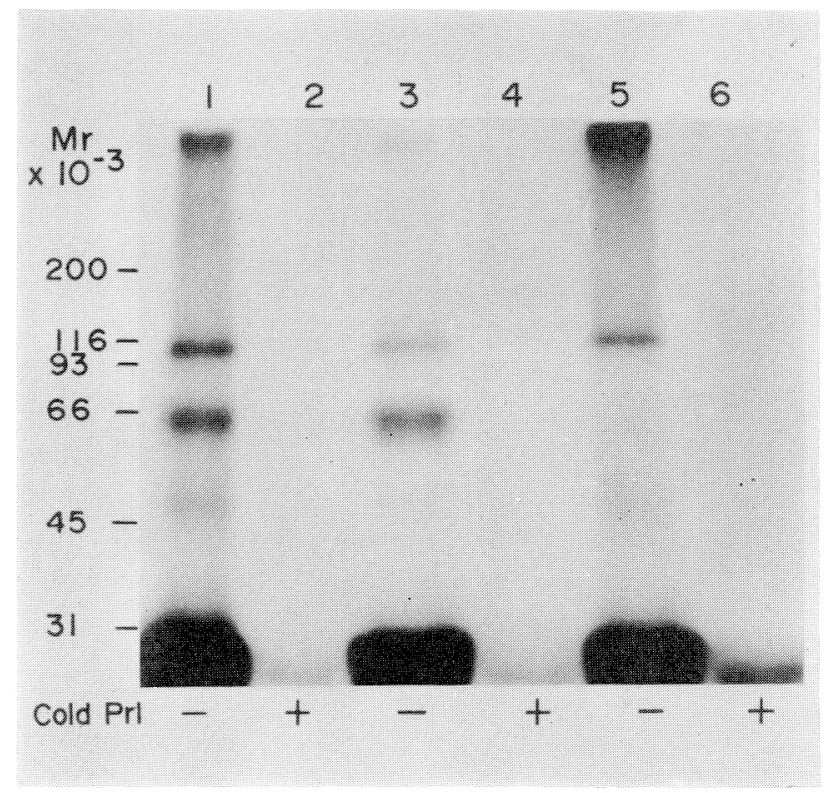

Fig. 5. Autoradiograph of ${ }^{125} \mathrm{I}-$ PRL covalently cross-linked to PRL receptors. PRL receptors in the Chaps extract (lanes 1, 2), Fr. A (lanes 3, 4) and Fr. B (lanes 5, 6) were incubated with ${ }^{125} \mathrm{I}$-PRL in the presence (lanes 2, 4 or 6) or absence (lanes 1, 3 or 5) of excess unlabeled PRL. Samples were denatured with SDS and DTT. Radioactivity of total (and non-specific) binding in the Chaps extract, Fr. $A$ and Fr. B were 22,000 $(3,900), \quad 19,900 \quad(2,300)$ and $20,500(4,000) \mathrm{cpm}$ per lane, respetcively.

\section{Discussion}

Charge heterogeneity of PRL receptors has be:n shown by isoelectric focusing and chromatofocusing (Sasaki et al., 1982; Waters et al., 1984 ; Mitani and Dufau, 1986). The latter two authors clearly separated the Triton-solubilized PRL receptors into three fractions of different pl. The Chaps- 
solubilized PRL receptors were separated into three fractions with the full recovery of the PRL-binding activity by ion-exchange chromatography. The PRL-binding activity in these fractions was greatly different: the amount recovered in the unbound fraction was the smallest and that in the 100-180 $\mathrm{mM} \mathrm{NaCl}$ fraction, the largest. Scatchard analysis showed that the Chaps extract contains 2.2 times more receptors with a high $\mathrm{K}_{\mathrm{d}}$ than the low $\mathrm{K}_{\mathrm{d}}$ type receptors in the $25-90 \mathrm{mM} \mathrm{NaCl}$ fraction. In the autoradiogram of the microsome $\mathrm{PRL}$ receptors, the band of the 83,200 species was more strongly labeled than the two other bands. In previous experiments (Sakai et al., 1986), the low $K_{d}$ type-PRL receptors were completely solubilized by $7.5 \mathrm{mM}$ Chaps, the high $K_{d}$ type-receptors being left in the microsome fraction. These results suggest that PRL receptors in the lactating mammary gland are mostly of the high $\mathrm{K}_{\mathrm{d}}$ type.

The mol wt of PRL receptors in several organs and species has been examined using affinity-labeling and SDS-PAGE. The migrated position of ${ }^{125}$ I-PRL differed in the presence or absence of DTT in denaturing buffer (Katoh et al., 1985). We confirmed above findings. In the mammary glands, a single species of PRL-binding subunit has been reported, the mol wt ranging from 32,000 to 42,000 (Haeuptle et al., 1983; Hughes et al., 1983 ; Necessary et al., 1984 ; Katoh et al., 1985). We detected a 36,800 species and two other PRL-binding subunits (mol wt, 83,200 and 20,800) in the Chaps extracts and microsomes. The high mol wt form of PRL-binding subunit (mol wt, $81,000-91,000)$ has been reported in the ovarian (Mitani and Dufau, 1986) and the Leydig cell PRL receptors (Bonifacino and Dufau, 1985). Autoradiography studies indicated that the three PRL-binding subunits were not bound to other protein by disulfide bonds, and that a 82,300 species did not disaggregate into a 36,800 species following the chemical treatments involved in affinity- labeling and SDS-PAGE. The lowest mol wt PRL-binding subunit was probably released from a receptor subunit with a mol wt of 82,300 and/or the holo-receptor. By sucrose gradient centrifugation under nondenaturing conditions, two species of PRL receptors (mol wt, 89,400 and 42,400) could be detected, their mol wt comparable with those estimated from SDS-PAGE and autoradiography. Moreover, Fr. A and Fr. B contained predominantly a 42,400 species and a 89,400 species, respectively. By gelfiltration chromatography of the Tritonsolubilized PRL receptors, much higher mol wt have been reported, ranging from 133,000 to 380,000 (Shiu and Friesen, 1974 ; Heauptle et al., 1983; Katoh et al., 1984 ; Yamada and Donner, 1985; Mitani and Dufau, 1986). In contrast, the mol wt of the Chapssolubilized PRL receptors in mouse liver (Liscia and Vonderhaar, 1982) and rabbit mammary glands (Necessary et al., 1984 ; Sakai et al., 1986) were low, ranging from 37,000 to 55,000 . It appears that the type of detergent has an influence on the apparent mol wt of the receptor. The relationship between these two PRL-binding subunits (mol wt of 36,800 and 83,200 estimated by SDS-PAGE) and their biological significance is under current investigation.

In conclusion, PRL receptors are separable into two species by ion-exchange chromatography. Two receptors are characterized as follows: (1) a high $\mathrm{K}_{\mathrm{d}}$ type receptor $\left(6.5 \times 10^{-11} \mathrm{M}\right)$ with a mol wt of 82,300 and (2) a low $K_{d}$ type receptor $\left(3.0 \times 10^{-11} \mathrm{M}\right)$ with a mol wt of 36,800 .

The number of high $K_{d}$ type PRL receptor isolated in Fr. B was approximately 2.2 times larger than that of the low $\mathrm{K}_{\mathrm{d}}$ type PRL receptors in Fr. A.

\section{Acknowledgements}

We thank Dr. H. A. Bern and Dr. S. Nandi of the University of California at Berkeley, for 
helpful discussions and suggestions during the preparation of this manuscript. The present work was supported by a grant-in-aid for scientific research from the Ministry of Education, Science and Culture of Japan (No. 61560296).

\section{References}

Bonifacino, J. S. and M. L. Dufau (1985). Lactogen receptors in rat leydig cells : analysis of their structure with bifunctional cross-linking reagents. Endocrinology 116, 1610-1614.

Haeuptle, M. T., M. L. Aubert, J. Djiane and J. P. Kraehenbuhl (1983). Binding sites for lactogenic and somatogenic hormones from rabbit mammary gland and liver. J. Biol. Chem. 258, 305-314.

Hughes, J. P., J. S. A. Simpson and H. G. Friesen (1983). Analysis of growth hormone and lactogenic binding sites cross-linked to iodinated human growth hormone. Endocrinology 112, 1980-1984.

Katoh, M., J. Djiane and P. A. Kelly (1985). Prolactin-binding components in rabbit mammary gland: characterization by partial purification and affinity labeling. Endocrinology 116, 2612-2620.

Katoh, M., J. Djiane, G. Leblanc and P. A. Kelly (1984). Characterization of antisera to a partially purified prolactin receptor: effect of prolactin binding in different target tissues. Mol. Cell. Endocrinol. 34, 191-200.

Laemmli, U. K. (1970). Cleavage of structure proteins during the assembly of the head of bacteriophage T4. Nature 227, 680-685.

Liscia, D. S., T. Alhadi and B. K. Vonderhaar (1982). Solubilization of active prolactin receptors by a nondenaturing zwitterionic detergent. J. Biol. Chem. 257, 9401-9405.

Liscia, D. S. and B. K. Vonderhaar (1982). Purification of a prolactin receptor. Proc. Natl. Acad. Sci. USA. 79, 5930-5934.

Luthe, D. S. (1983). A simple technique for the preparation and storage of sucrose gradient. Anal. Biochem. 135, 230-232.
Martin, R. G. and B. N. Ames (1961). A method for determining the sedimentation behavior of enzymes : application to protein mixtures. $J$. Biol. Chem. 236, 1372-1379.

McEwen, C. R. (1967). Tables for estimating sedimentation through linear concentration gradients of sucrose solution. Anal. Biochem. 20, 114-149.

Mitani, M. and M. L. Dufau (1986). Purification and characterization of prolactin receptors from rat ovary. J. Biol. Chem. 261, 1309-1315.

Necessary, P. C., P. A. Humphrey, P. B. Mahajan and K. E. Ebner (1984). Purification of rabbit mammary prolactin receptors by acid elution from a prolactin affinity column. J. Biol. Chem. 259, 6942-6946.

Sakai, S., F. Ike, K. Kohmoto and T. Johke (1986). Separation of rabbit mammary-gland prolactin receptors by ion-exchange chromatography, h. p. l. c.-gel filtration and ultracentrifugation. Biochem. J. 237, 647-653.

Sakai, S., M. Katoh, P. Berthon and P. A. Kelly (1985). Chracterization of prolactin receptors in pig mammary gland. Biochem. J. 224, 911922.

Sasaki, N., Y. Tanaka, Y. Imai, T. Tsushima and F. Matsuzaki (1982). Different characteristics of solubilized lactogen receptors from livers of pregnant and non-pregnant femal rats. Biochem J. 203, 653-662.

Scatchard, G. (1949). The attraction of proteins for small molecules and ions. Ann. NY. Acad. Sci. 51, 660-672.

Shiu, R. P. C. and H. G. Friesen (1974). Solubilization and purification of a prolactin receptor form the rabbit mammary gland. $J$. Biol. Chem. 249, 7902-7911.

Waters, M. J., S. Lusins and H. G. Friesen (1984). Immunological and physicochemical evidence for tissue specific prolactin receptors in the rabbit. Endocrinology 114, 1-10.

Yamada, K. and D. B. Donner (1985). Evidence that non-covalent forces, thiol and disulphide groups affect the structure and binding properties of the prolactin receptor on hepatocytes from pregnant rats. Biochem. J. 228, 383-390. 